\title{
Liability in International Space Law
}

\author{
Kyrylo Muraviov \\ Doctor of Law, Associate Professor, Interregional Academy of Personnel Management \\ (Kyiv, Ukraine). \\ E-mail: donkiril@ukr.net \\ https://orcid.org/0000-0002-4422-4116
}

\section{Serhii Didenko}

Doctor of Law, Professor, Kherson Institute of "Interregional Academy of Personnel

Management" (Kherson, Ukraine)

E-mail: didenko19520@ukr.net

https://orcid.org/0000-0003-3349-4046

\section{Roman Mkrtchian}

Ph.D. in Law, Associate Professor, Kherson Institute of "Interregional Academy of Personnel

Management" (Kherson, Ukraine)

E-mail:mroman1985@ukr.net

https://orcid.org/0000-0001-7524-7401

The article is devoted to the analysis of the norms of international and national legislation regulating the issue of liability in international space law and investigation of the grounds for liability in space law. Special attention is paid to the forms and types of legal responsibility for the violation of law in the domain of space activities. The study explores the issue of absolute liability in international space law. The analysis of space law makes it possible to conclude that both in international law and international space law, material liability of states for non-compliance with international law norms in the implementation of space activities is complemented with political liability. There is made a conclusion about the necessity of making amendments to the Law of Ukraine "On Space Activities" aimed to foresee the norms of liability for taking space offences. The solution to these problems is hampered primarily by the lack of experience and judicial practice in this area. Further research in this field will contribute to the development of a systematic approach to international legal regulation of liability in space law.

Keywords: international public law, international private law, space law, liability, liability grounds, absolute liability, offences, space activities, convention, national sources, insurance

Received: January 17, 2019; accepted: February 20, 2019

Advanced Space Law, Volume 3, 2019: 71-82.

https://doi.org/10.29202/asl/2019/3/6
(C) Muraviov, Kyrylo, 2019
(C) Didenko, Serhii, 2019
(C) Mkrtchian, Roman, 2019 


\section{Introduction}

One of the most important institutions in international law is the institution of international liability. International legal responsibility denotes the legal implications that occur for a subject of international law violating current norms of international law and their international commitment. In addition, this is one of the legal means to ensure compliance with these norms and obligation to pay for damages. Almost all world legal systems recognize international liability of the states violating the norms of international law and their obligations under international contracts.

Awareness of the importance of space as a source of welfare and security has led to realizing the fact that there are a number of aspects related to the space activities of states which may be subject to dispute or cause offenses resulting in liability. The issue of liability in the international space law is becoming even more important because of the growing research and development of the space industry in the whole world. The issue of liability in space law is regulated by the norms of international law that requires reforming. The process of space development leads to the emergence of new relations of different kinds, which need to be regulated and regimented. Since space activities can cause damage entailing liability and need for reimbursement for damages, the enforcement of liability in international space law acquires special significance.

The aim of the research is to implement a comprehensive legal analysis of the condition and perspectives of the development of international law norms, which regulate the issues of liability in international space law when implementing space activities.

\section{Research findings}

Space activities are constantly accompanied with different types of risks, therefore there arises quite an appropriate problem faced by a number of space countries, i.e. to continue exercising the space activities and deliberately risk or confine themselves to the existing situation and make use of existing treasures. This context gives rise to a logical question about security as a fundamental state function of the state aimed at ensuring civil security [Dzvinchuk \& Kachmar, 2018]. This concern of the state manifests itself by granting permission to commercial organizations to get engaged in the applied types of space activities. The state should take good care of such issues as ensuring control and public supervision over the activities of enterprises, which are engaged in launches of missiles and satellites into space, that are a priori the sources of elevated danger.

Since the liability in international law is a legal implication, which occurs for the entity of international law, having violated current norms of international law and their international obligations under international contracts. Legal implications after violations of contractual or ordinary norms of international law may affect a delinquent state, an injured state or a Group of States, or the whole international community, as well as international governmental and nongovernmental organizations. These consequences, as well as forms and volume of liability can be different depending on: severity of the offense, size of the damage caused, nature and degree of the danger of the offense and, in particular, may involve: responsibility for aggression, genocide, apartheid, racial discrimination, violation of laws and war customs, for rejection of granting independence to colonial countries and peoples; obligation of the delinquent state (group of delinquent states) to compensate for the damage done to other subjects of international law, and in separate cases to their legal entities and individuals; application of 
compulsory measures to a delinquent state in accordance with international law up to setting an economic blockade and using military power.

The reason for international liability of the state is its committing an offence. That is, to observe that there is an international offense, it is necessary to establish first, that there is a behavior which is manifested in action or inaction, which can be set as an obligation for a state in accordance with international law, and, secondly, that such a behavior is a violation of international commitment of this state. Thus, an international law offence is action or inaction of the state that violates its international commitment established by the norm of international law.

Regarding the forms of legal responsibility, they normally imply the methods leading to the consequences unfavorable for an offender relsulting from its commitment of an international offense. There may be distinguished two forms of legal responsibility of a state for the committed international legal violation: both material and political. Depending on the nature of offence, an offender may be faced with either only material liability or only political, or both.

Each form of legal responsilbility, in its turn, is divided into types. Within the framework of material responsibility, these are restitution (return of seized values, restoration of destroyed objects) or reparation (reimbursement of the cost of the incurred damage). Both types of responsibility are of reparative character. The types of political responsibility are diverse enough: from satisfaction (e.g., apologies, punishment of the guilty) to economic and other sanctions, up to application of the military power.

Among all forms of responsibility in international space law, the top priority belongs to the so called absolute (objective) responsibility. In Article 2 of the Convention on Liability, it is stated that "the launching state takes absolute liability for the damage, caused by its space object on the surface of Earth or flying spacecraft", and establishes basic principle of space liability [Convention, 1972].

In the domain of international legal relations, objective (absolute) liability may arise most frequently as a result of a state's involvement in managing such sources of elevated danger, as marine, aircraft, spacecraft, different nuclear enterprises and installations, etc.

In the science of international law, a statement was made that the issues raised in the Convention on Liability, are beyond the framework of space law and are related to the problem of responsibility in international law in general. In addition, the raised issues have general theoretical significance as well. In this connection, there are required some comments on the point of view, according to which one of the most important elements of the grounds for objective liability together with damage is considered to be the presence of causal link between an action (in this case, a space object) and the damage, that has been done. However, there is another point of view: in the absence of causal link, there is no liability for the damage, caused by a space object on Earth. There is no doubt that damage is always a result of any action. In such a context, one can talk about causal telationship between the action of nature forces and the damage inflicted by them.

Summarizing the above and with reference to the peculiarities of space activities, it is worth mentioning that liability in international law is possible both for violating the norms of international law - international legal responsibility (political and material), and for violating the norms of the national law — criminal, administrative, civil and disciplinary. Taking into account the territorial factor and the factor of membership in a specific country (citizenship), there are possible cases of compensation for damage according to the national law and in accordance with the provisions of the Convention on Liability. 


\section{Subjects and nature of liability for the inflicted damage}

The issue about the subject (subjects) and the nature of liability for the inflicted damage in case of falling of a space object or its fragments on the territory of Ukraine and beyond its borders deserves special attention.

Article 25 of the Law Ukraine "On Space Activities" implies that "liability for damage caused in course of space activities, as well as the order of assessing the extent of this damage, that is subject to recovery, are set respectively to current legislation of Ukraine". Article 29 of this Law stipulates that violations of legislation regulating space activities in Ukraine may lead to disciplinary, civil law or criminal liability in accordance with current legislation of Ukraine [Law, 1996]. In other words, current legislation of Ukraine does not contain any norms that define the specifics of legal responsibility for damage caused by space activities, therefore the general standards of legal responsibility are applied. In view of this, in case of necessity one should further analyze the appropriate articles of the Civil Code of Ukraine, which specifically regulate the issues of compensation for civil damage.

Proceeding from the fact that Ukraine does not have its own cosmodrome and launches space objects from the territory of other states, that according to Article I of the Convention on responsibility is recognized by the launching states, and in accordance with article $\mathrm{V}$ are the participants of a joint launch and undertake common liability, there appears an issue about the nature of liability in case of possible inflicting damage to the territory of a launching state [Convention, 1972].

In addition, the Convention on Liability implies that its provisions are not applicable to the cases of damage caused by a space object of the launching state and its citizens. That is, based on the provisions of the Convention on Liability, the state, from the territory of which Ukraine performs the launch, as a launching state must compensate for the damage that is not based on the provisions of this Convention, but complies with the national legislation. Citizens of this state have the right to claim compensation for damage in accordance with the provisions of the Convention on Liability from Ukraine only. However, in most cases, the state from the territory of which a spacecraft is launched, does not want to undertake liability for the damage, inflicted by the object of another state that is launched from its territory.

As a rule in international practice, when the use of foreign territory for launching space objects is in question, the states interested in bilateral contract stipulate the issues of financial liability in case of inflicting the third side without change of its status "launching state". Accordingly, one should proceed from Article 17 of the Law of Ukraine "On Space Activities" claiming that Ukraine as a subject of international space law undertakes liability in accordance with the generally recognized norms of international law and provisions of international treaties of Ukraine, i.e. the law directly envisages the implementation of norms of international law in national legislation of Ukraine [Dmitriev, 1998: 124-126].

Therefore, as it is properly stated by Igor Andrushko, neither the mentioned article nor other articles of the law specifically indicate, according to which exactly "generally recognized norms of international law and provisions of international treaties Ukraine bears responsibilty" [Andrushko, 2006: 110].

In this way, it can be determined that liability in international space law depends on the domain of either private law or public law relations. That is, whether these are the relations of international public law or private international law, since their subject matter is different, and the sources that regulate relations are even more different. In the case of relations of a public 
character, the main role is played by international treaties, and if these relations are private, then the national legislation is taken as a basis.

Consequently, even more important role is played by the national legislation, particularly concerning the issue of compensation for damage. In this respect, one should not forget about the norms of international private law in relation to the subjects that cause damage, the type of connecting factor being of the ultimate importance, which must be applied when resolving the issues of compensation for damage.

That is, there should be established the statute of tort liabilities.

In the international private law, the statute of tort liabilities implies the legal order, which indicates the conditions and amount of liability, legal grounds for restriction or release from it, distribution of liability, right grounds for restriction or release from it, division of liability between a delinquent and a victim, nature of losses, which can be reimbursed, methods and size of compensation, admissibility of assignment right on reimbursement, circle of persons who have the right on compensation of the incurred losses. That is, the definition of a statute of tort liabilities with a foreign element gives an opportunity to find out which legal order is exactly applied for the settlement of the similar relations [Dennerley, 2018].

The unification of laws of different states in the sphere of space liability turns out to be rather difficult. In this case, the regulation of non-contractual obligations with a foreign element is most often based on conflict of norms. Conflicting norms make provision for the formation of the charter of tort liabilities - a set of material law and national law norms chosen on the basis of conflicting norms. Despite essential differences in regulating tort legal relations by material law of different states, conflicting regulation in this issue is almost identical.

That is, liability in private law relations can arise as a result of causing damage by a delinquent. Solving the issues about compensation for damage requires application of such types of conflicting connecting points. To determine the statute of tort liabilities, the following connecting points are applied: the law of place (lex loci) causing damage; the law of the state of jurisdiction (lex fori); the law of the flag; the law of a vehicle registration place; the personal law (lex personalis) of a party (parties); the law, chosen by parties (a party) of tort liabilities. Among the listed types of conflicting connecting points, we may be interested in: the law of the place causing damage; the law of a vehicle registration place; the personal law of party (parties). The most common is the law of place causing damage. While it can take place in the outer space, then it is the outer space that is the territory with the legal regime, but in case of damaging space objects, which are the property of individual states or organizations, accordingly there may arise a problem of compensation for damage according to the international treaties between the subjects or referring to the norms of tort liabilities in private international law.

As for the tort liabilities, the generally accepted conflicting connecting point in classic international private law was the application of law and order of places causing damage, i.e. the law of the state inflicting damage, i.e. the law of the place causing damage.

Current legislation of Ukraine also defines the law of the place causing damage. Thus, Part 1 of Article 49 of the Law of Ukraine "On International Private Law" establishes that the rights and obligations arising as a result of causing damage are determined by the law of the state, in which an action or another circumstance occurred becoming the basis for the claim about compensation for damage.

However, the latest trends in the development of international private law are indicative of the gradual loss of popularity of this conflicting connecting point. Legislation and judicial 
practice try to most accurately take into account all the circumstances of the case and choose the law that is characterized by the closest connection with the offense.

Ukrainian law, regardless of recognition of the law of the country causing damage as a general rule as well as the law of other states reacting to new trends, implies exceptions of certain legal relationships to it. Thus, Part 2 of Article 49 of the Law of Ukraine "On International Private Law" stipulates that the rights and obligations arising as a result of causing damage abroad, if the parties have a place of residence or citizenship in one state, are determined by the law of that state.

In our opinion, a means of transport is taken to mean a particular spacecraft, a spaceship registered in a respective country, and has clearly identified data about its affiliation. And in case of its causing damage, an owner of an object (an apparatus, a ship, a satellite, etc.) will carry the responsibility. But, it is possible to apply the personal law of a party (parties), i.e., the settlement of relations in accordance with the national legislation.

The defining element in the charter of tort liabilities is the conflict of law in its components: volume and connection. At the same time, with the help of the volume of the conflict of law, there are determined the type and range of relations that are subject to a certain statute, the scope of its action, the list of issues that are solved by it, and by means of the connecting point of a conflict of law, the material law of an applicable country is determined, i.e., the definition of the content of the relevant statute of tort liabilities is given.

Determining application of a law or order may depend on many factors that have a decisive significance in the nature of tort liabilities with the participation of a foreign element, namely: 1) defining of the grounds for compensation for damage; 2) qualifying an act just as a tort; 3 ) determining the extent of the tort law of the damage caused; 4) defining the amount of damage to be compensated; 5) determining the methods and order of compensation for the damage caused.

\section{Regulation of liability in some countries}

In many countries, space activities must necessarily be insured, which makes it possible to recover damages in the event of certain situations (insurance cases). National licensing regimes may, in particular, include the requirements on entering of space launchers into insurance contracts in the event of causing damage to a third party as a result of launch or in other circumstances in order to demonstrate that they have sufficient means to reimburse the victim parties. Insuring the risks connected with launching is often undertaken by both main underwriter and several other reinsurance companies.

Therefore, in the US, licensees for space activities are required to insure their responsibility or demonstrate their solvency to cover the maximum possible damage to third parties and the government as a result of their space activities. In addition, any agreement between NASA and a user of a spacecraft may provide that the US government will insure the user from claims (including reasonable costs or costs of settling a claim) by third parties in cases of death of people, bodily injuries, loss of property or damage to property in the result of the activities related to the launch, navigation or rescue of the spacecraft, but only to the amount not covered by the liability insurance contract, provided that such insurance may be limited to the claims not presented in connection with the actual negligence or intentional unlawful actions of the user [Kosmichne, 2001: 317] 
The Australian Law "On Space Activities" regulates the issue of liability for damage caused by space objects. Article 63 provides that this part is applied to cases of damage caused by a space object if: an object is launched using a launch complex in Australia; or Australia is the launching state regarding the facility; damage is caused within the period of liability established for launch. The law of Australia "On Space Activities" also applies to the damage caused by a space object if: an object is returned to a place in Australia; damage occurs during the period of liability established for return. Article 63 of the Australian Law "On Space Activities" applies to the damage cases, considered above, if: damage occurs on the Earth's surface, in the air or in the outer space; damage occurs in Australia or abroad; launch or return is authorized in accordance with this Law; the release certificate includes the return [Kosmichne, 2001: 165].

In addition, it is also implied that the provisions of national law do not restrict Australia in fulfilling any obligation to compensate for damage in accordance with the Liability Convention or in accordance with international law. This law defines in detail the issues of liability for damage inflicted on a third party [Kosmichne, 2001: 166].

Section 4 of the Australian Law on Space Activities regulates the issue of claims for compensation filed by foreign states, in particular Article 74 is applied in accordance with the Liability Convention or other norms of international law if: a foreign state sues for compensation for damage to Australia; Australia must recover damages in any way. The party responsible for the appropriate launch or return must pay the amount equivalent to the smaller one of the following amounts: the amount of this compensation if the launch or return of the space object has been authorized by the launch permit or certificate for launching abroad, being applicable to the relevant article of the law - the insured amount for the permit or certificate [Dmitriev, 1998: 124-126].

An important aspect is that some national legislative acts on the issues of space activities contain specific norms that regulate liability for damage caused by space objects, norms in common law, e.g. norms of tort law or environmental law, mentioned above. National legislative acts on the issues of space activities may also include specific provisions on investigations of launch accidents, etc.

In addition to the provisions on reimbursement of damage to the injured parties in the result of the launch, many national legislative acts also contain the provisions guaranteeing such reimbursement in money. Such a requirement can protect not only the injured party, but the national government as a Party of the Convention on Liability, guaranteeing compensation for damage performed by the launching party [Convention, 1972].

\section{Insurance of space activities in Ukraine}

At the present stage in Ukraine, there is an inadequately developed mechanism for civil legal regulation of relations in the sphere of mandatory insurance with implementation of space activities that negatively affects provision of reliable insurance protection of property interests of primarily the subjects of space activities in the process of their implementation of space projects and programs. This circumstance requires filling the existing gaps in the legal regulation of the relevant civil law relationships.

Insurance of space activities should be understood as a comprehensive insurance industry covering personal insurance, property insurance and civil liability insurance. It is the complex nature of insurance in the field of space activities that provides reliable and universal insurance 
protection of property interests of subjects of space activities in the process of exploration and use of outer space.

The most important place in the regulation of insurance relationships between the insurer and the insured is occupied by the norms of the civil law, which are regulated by the contract relations when implementating insurance in the domain of space activities.

Insurance when implementing space activities is an unassisted complex branch encompassing personal insurance, property insurance and civil liability insurance in case of causing damage to the third persons in the process of these activities. Complexity of this special insurance is conditioned by the necessity of insurance protection of property interests of the subjects of space activities in connection with production and exploitation of space technology for the purpose of research of the use of outer space.

Underwriters can not be individual citizens, since they are not recognized as subjects of space activities. That is, underwriters when conducting mandatory insurance in the field of space activities can be presented by any enterprises, institutions and organizations (incl. international and foreign), which perform space activities and want to have a financial guarantee of insurance protection from possible losses.

Consequently, one can prove the importance of concluding an insurance contract and predicting all the conditions of the occurrence of an insurance case. That is, the peculiarities of an insurance contract in the field of research and use of outer space can include the need for its reflection of risks arising in the process of implementation of space activities, with regard to which the degree of risks probability as compared to other insurance contracts is unknown. First of all, this is due to the insufficiency of the relevant statistical data, in particular for insurance cases.

To properly develop the effective insurance market in Ukraine in the process of implementation of space activities, it is necessary to resolve a number of legal problems associated with insurance of life from misfortunes.

Today, the Law of Ukraine "On Insurance" indicates that it is prohibited to carry out insurance activities on the territory of Ukraine to be performed by underwriters who are nonresidents, except for the following cases of types of insuring activities:

- exclusively insuring the risks related to marine transportation, commercial aviation, launches of rockets and freight (including satellites), in case if property interests are an object of insurance connected with goods, which are transported, and/or a means of transport by which they are transported, and/or any liability that arises in connection with such transportation of goods;

- insurance mediation such as brokerage and agent operations in relation to: reinsurance, exclusively with the insurance of the riskc connected with martine transportation, commercial aviation, launches of rockets and freight (including satellites) in case if property interests are an object of insurance, connected with goods, which are transported, and/or a means of transport by which they are transported, and/or any liability that arises in connection with such transportation of goods.

In addition, the following types of insurance activities concerning space are determined:

- insurance of objects of space activities (Earth's infrastructure), the list of which is approved by the Cabinet of Ministers of Ukraine after submission of the central body of executive power, which ensures formation of the state policy in the domain of space activities;

- insurance of civil liability of subjects of space activities; 
- insurance of objects of space activities (space infrastructure) which is a property of Ukraine as for the risks connected with the preparation of space technology for launching on a launching site, its launch and operation in outer space;

- insurance of liability as for the risks related to preparation to launching of space technology on a launching site, its launch and exploitation in outer space [Law, 1996].

It may be expedient to introduce changes and amendments to the Law of Ukraine "On Insurance" in the part of introducing mandatory personal insurance of life for spacecraft crew (astronauts) on the territory of Ukraine.

In relation to the civil law regulation of insurance relations in the sphere of space activities, it is appropriate to adopt the Law of Ukraine "On mandatory insurance when implementing space activities in Ukraine" devoted to regulating the order and rules of mandatory insurance, in particular to determining the number of people who are the underwriters and the insured, the size of the insured sum according to the insurance contract. It is especially expedient to approve a standard form of insurance contract when implementing space activities.

\section{Application of liability agreements}

In accordance with paragraph 1 of the Convention on Liability, when two or more states jointly conduct a launch of a space object, they carry solid liability for any damage. Clause 2 of Article 5 of the given Convention implies that the members of a joint launch may conclude treatis about distribution of financial obligations among themselves [Convention, 1972]. Such agreements do not affect the right of the state, being inflicted the damage, to demand the whole compensation payment for damage on the basis of this Convention from any or all of the launching states, which undertake solid individual responsibility. Many treaties on liability are not applied in the case if the liability arise as a result of deliberate or sometimes gross negligence.

For example, liability regime of the European Space Agency (ESA) is governed by the Resolution of the Council of the ESA on the Agency's Legal Liability [Resolution, 1997]. According to Article A-I of this resolution the Agency shall insure Member States or States Parties of space programs or space activities of liability, which they carry in the result of implementing such programs or activities if the Agency gives its consent or if the state bears responsibility as a "launching state" as defined in the Convention on Liability.

However, if a state is qualified as a "launcing state" as for the named activities, then it shall reimburse the agency the compensation amount, recovered from the Agency, if damage is due to gross negligence, intentional action or inactivity on behalf of the state or persons acting from its name. Article A-II of this resolution states that if a claim for compensation is brought to a Member State or states participating in the Agency's program, this state immediately holds consultations from the Agency, and the Agency can join the lawsuit if it is admissible by the applicable law, and may be replaced by the appropriate state, if this state will ask for it. In addition, any Member State or State Party may join an appropriate state or the Agency in litigation consideration if it is permitted by the applicable law, and an appropriate state follows the guidelines, jointly agreed by the Agency and this state as for both a lawsuit and claim settlement. The states taking part in the program always submit their claim for compensation primarily to the Agency. The Agency's expenses incurred due to compensation for damage are charged from the states participating in a corresponding program, independently of the upper limit agreed upon as for their participation in this program. Contributions by the states are proportional to their financial contributions to 
the program at the time when the damage was caused if it was caused when implementing the program or the time of the program completion if the damage was caused after that time. In these cases, when the risk is covered by insurance, the appropriate premium insurance is charged to the account of the program [Andrushko, 2006: 130].

One of the types of liability treaties is the one "On mutual rejection of the liability requirement", on the basis of which partners of a space flight agree not to file a lawsuit as for damage compensation against each other. The partners can take responsibility for loss of their own property, loss of property or corporal damage of their employees due to appropriate actions. As in the case with many other agreements on liability, a number of treaties on mutual rejection of liability requirements are not applicable if the liability comes as a result of deliberate unlawful action or gross negligence.

\section{International cooperation as a key foundation for improving the liability issues}

Subjects of liability in international space law all can act as states more often, except legal entities. When the liability relations occur especially in the case when the relations are of international public nature, the question about international contracts arises, Ukraine being their participant, as well as about the level of its cooperation with other states in the sphere of space activities.

Modern world market of space services and technology from the legal point of view represents a system of publicly and privately legal ties that mediate relations between such subjects as states, international intergovernmental organizations, individuals and legal entities, including various international non-governmental organizations and transnational corporations. And if until recently, the activities within the framework of the world market of space services and technology were mainly associated with the cooperation of states and intergovernmental international organizations, starting from the 80 s this market has been more and more joined with new entities (private firms, banks, other individuals and legal entities) that leads to new legal problems.

Space Law of Ukraine is in the process of dynamic development, and for effective regulation of relations between national subjects of space activities, on the one hand, and rightful integration of the country to the world market of space services and technology, on the other, it requires perfection.

Implementation of the standards and principles of international space law in the legislation of Ukraine is quite differentiated. Generally recognized standards and principles of space activities are sufficiently fully implemented in Ukrainian legislation (except, apparently, liability issues). At the same time, among specific legal regulators of the world market of space services and technology, only the rules of licensing and export-import control have found their proper reflection in the national law of Ukraine. Another significant disadvantage is that most of these rules are not established de jure, but in the form of government regulations or departmental acts.

Ukrainian space law does not formulate the problems of international cooperation of Ukraine fully enough, the issues which receive much more attention in the laws of most space states in the world. In this connection, it is worthwhile to take measures to expand space cooperation within the framework of the EU, the ESA, and also specialized international organizations. 
Also, the additional directions for integration of Ukraine into the world market can be the following: asserting the leading role of Ukraine in space projects of the countries of the Central European Initiative; participation in a joint project for using space technologies to build a European system of environmental safety within the framework of the international program of the Council of Europe; participation in creation of the European-wide system of navigation on the basis of space-based means; conversion projects on the relevant conversion use of rockets for scientific and commercial cargo launches and production of medical and biological preparations in conditions of micro gravity.

Harmonizing the national law of Ukraine with international space law and space law of foreign countries is one of the factors predetermining the establishment of Ukraine as a legal state, a guarantee of civilized entry of our state to the community of world space states, a guarantee of rightful and fair participation of the country in the world division of labor in space industry, efficient activities of our country in the world market of space services and technology.

Today, new spheres of space technology application and new types of space activities have emerged, which were even impossible to predict in the first 20-30 years of the space era, the time of establishing international space law. Space activities and primarily the relations of the subjects of these activities in the world market of space services and technologies are more often manifested under the influence of spheres of international economic law, which reduces the boundary between public and private law.

Thus, Ukraine as a state should not only interact with other states, but with different kinds of corporations and companies that carry out space activities. For that, to enter into relations with them it is necessary to offer something, but meanwhile Ukraine has almost nothing to offer in the field of international space law from a practical point of view.

\section{Conclusions}

Main international treaty, which regulates the issue of liability in the international space law, is the Convention on Liability. The Convention was adopted to fulfill the provisions of the Outer Space Treaty, namely its Article VII, which stipulates that every State Party of the Treaty that implements or arranges a launch of an object into outer space including the Moon and other celestial bodies undertakes international liability for damage caused by space objects. In addition, each State Party of the Treaty from the territory or installations of which an object is launched, bears international liability for damage inflicted by such objects or their composite parts on Earth, in air or outer space including the Moon and other celestial bodies, another State Party of the Treaty, individuals or legal persons.

In connection with the constant expansion of the boundaries and forms of space activities, there appears a need to update the Convention on Liability or conclude an appropriate agreement for each individual type of liability. It is especially true that the Convention accepted 40 years ago does not fully meet the present conditions and achievements in the space industry.

While solving the issue of liability in international space law, it should be judged who has caused damage: a subject of international public law or international private law. Since, in the first case, the issue of compensation for damage and liability in general will be resolved according to international treaties. And in the second case, everything depends on the type of factor which specifically regulates the relations of international private law. It is due to the fact that the space research is sometimes carried out not by the governments of the countries, but 
separate individuals and legal persons, that leads to the change of legal relations type and in case of solving the issues of liability the subjects are not states, but separate individuals and legal entities.

Consequently, to improve the institute of liability in the international space law, it is necessary to update the national laws of countries-parties of various space programs, as well as improve the sources of international law concerning liability in international space law.

\section{[D] References}

Andrushko, Igor Petrovich. Cosmic right: concept and content: dis ... cand. jurist sciences: 12.00.01 / National Academy of Sciences of Ukraine; Institute state and rights them. V.M. Koretsky. K., 2006.

Convention on International Liability For Damage Caused by Space Objects, March 291972. //A/AC.105/722. https://www.un.org/en/documents/decl_conv/conventions/damage. shtml

Dmitriyev, Anatoly. Problems Implementation Norms International Law National Law Ukraine. Problems Harmonization Legislation Ukraine With International right: Materials scientific and practical conference. - K.: Institute Legislation The Verkhovna Rada of Ukraine, 1998.

Dennerley, Joel A. State Liability for Space Object Collisions: The Proper Interpretation of "Fault" for the Purposes of International Space Law. The European Journal of International Law, 2018. Vol. 29 №.1, 281-301. https://doi.org/10.1093/ejil/chy003

Dzvinchuk, Dmytro, and Oleksandra Kachmar. Cyber-aggression as the Problem of Interaction in Space Exploration. Philosophy and Cosmology, Volume 21, 2018. https://doi. org/10.29202/phil-cosm/21/6

Kosmichne Pravo Ukrayiny: Zbirnyk nats. i mizhnar. pravovykh aktiv. Uporyad.: I.P. Andrushko, O.V. Byehlyy; Vidp. red. N.R. Malysheva ta YU.S. Shemshuchenko. Kyiv: Yurinkom Inter, 2001.

Law of Ukraine. On space activities. № 502/96-VR from November 15 1996. https://zakon. rada.gov.ua/laws/show/502/96-us

Law of Ukraine. Pro strakhuvannya. № 85/96-VR, 7 March 1996. https://zakon.rada.gov.ua/ laws/show/85/96-print/print

Resolution 1803 (2008) adopted by the Security Council at its 5848 meeting, on 3 March 2008. https://zakon.rada.gov.ua/laws/show/995_g94

Resolution on the European Space Agency's industrial policy. ESA/C-M/CXXIX/Res. 1(Final), on 4 March 1997. https://download.esa.int/docs/LEX-L/Ministerial-CouncilResolutions/Meeting-C-M129(Paris,4Mar1997)/ESAC-MCXXIXRes.1(Final).pdf 